\begin{tabular}{|l|l|}
\hline Prefacio a la segunda edición & Titulo \\
\hline Thompson, Lanny - Autor/a; & Autor(es) \\
\hline $\begin{array}{l}\text { En: Nuestra isla y su gente : la construcción del "otro" puertorriqueño en Our islands } \\
\text { and their people. San Juan : CIS, 2007. ISBN 979-1-932992-03-0 }\end{array}$ & En: \\
\hline San Juan & Lugar \\
\hline CIS, Centro de Investigaciones Sociales & Editorial/Editor \\
\hline 2007 & Fecha \\
\hline & Colección \\
\hline $\begin{array}{l}\text { Identidad nacional; Política; Historia; Libros; Discurso colonial; Retórica narrativa; } \\
\text { Fotografía; Puerto Rico ; }\end{array}$ & Temas \\
\hline Capítulo de Libro & Tipo de documento \\
\hline $\begin{array}{l}\text { http://bibliotecavirtual.clacso.org.ar/Puerto_Rico/cis-uprrp/20120808013537/00prefaci } \\
\text { o.pdf }\end{array}$ & URL \\
\hline $\begin{array}{l}\text { Reconocimiento-No comercial-Sin obras derivadas 2.0 Genérica } \\
\text { http://creativecommons.org/licenses/by-nc-nd/2.0/deed.es }\end{array}$ & Licencia \\
\hline
\end{tabular}

Segui buscando en la Red de Bibliotecas Virtuales de CLACSO

http://biblioteca.clacso.edu.ar

Consejo Latinoamericano de Ciencias Sociales (CLACSO)

Conselho Latino-americano de Ciências Sociais (CLACSO)

Latin American Council of Social Sciences (CLACSO)

www.clacso.edu.ar

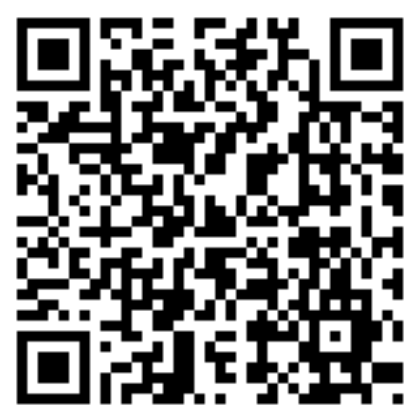




\section{Prefacio a la Segunda Edición}

La primera edición de este libro, agotada hace algunos años, se publicó en 1995. Desde entonces he estado dedicado al estudio de las imágenes y los textos producidos en los Estados Unidos sobre las varias islas, diversas y dispersas, bajo su dominio político a partir de 1898. Esta segunda edición, revisada y ampliada, propone atender algunos problemas analíticos y metodológicos evidentes en la primera. Por un lado, he tratado de responder a la aguda crítica acerca de los límites de usar un libro "pintoresco" y hasta fantasioso como fuente única para el análisis histórico 1 Mi respuesta a este problema se encuentra principalmente en las breves secciones nuevas sobre el problema imperial, el discurso colonial y la cuestión de cómo gobernar. He argumentado, tanto en el texto como en las notas al calce, que el libro Our Islands and Their People es un ejemplo del paradigma que comparten todos los libros populares acerca de las "nuevas posesiones" 2-2Más aún, a pesar de diferencias superficiales en cuanto a los detalles, hay una continuidad discursiva entre los libros populares, los informes oficiales y los debates legales. Además, hay una correspondencia entre las diferentes representaciones simbólicas y los distintos sistemas de gobierno establecidos por el congreso estadounidense en las islas que quedaron bajo su control a partir de 1898. Por otro lado, he tratado de sobrepasar los límites interpretativos de estudiar a Puerto Rico sin hacer referencia a los otros territorios que constituían el gran proyecto de expansión de ultramar de los Estados Unidos. Preguntas acerca de la unicidad del caso puertorriqueño no se pueden contestar de manera aislada. Intento remediar este problema mediante algunos breves apuntes comparativos, especialmente en la nueva sección sobre cómo gobernar. No obstante, la comparación sistemática de todas las islas bajo el dominio estadounidense sobrepasa el propósito de este libro; este asunto lo he atendido en otras publicaciones. $\underline{3}$

En los últimos años me he dado cuenta de que existe bastante interés en utilizar la fotografía como documento histórico. Dicho interés me ha brindado la oportunidad de dar varios talleres a estudiantes, maestros y profesores en diversos contextos pedagógicos. Por tal razón, en esta segunda edición he incluido algunas reflexiones metodológicas en una nueva sección titulada "Preludio: La paradoja fotográfica". Además, he añadido una sección didáctica en la cual analizo la fotografía de la portada mediante el examen cuidadoso de la misma y su comparación con siete fotografías adicionales.

El grueso de la edición original se queda intacto aunque he retocado y revisado el texto y su argumento. Además, he reorganizado las primeras tres secciones bajo una sola rúbrica: “Nuestra Isla y su gente". Igualmente, he reorganizado las dos secciones originales sobre las estrategias y fundamentos del discurso colonial bajo una sola rúbrica: “El discurso colonial”. Finalmente, todas las traducciones en la primera edición han sido reemplazadas por las acertadas traducciones de Cristina Vélez. $\underline{4}$ 
Para promover la distribución y proveer un formato más atractivo para ver y estudiar las fotografías, esta segunda edición incluye un CD con una versión digital del libro. También se ofrecerá acceso al libro en su versión digital a través de la Internet.

\section{Preludio: La paradoja fotográfica}

La palabra fotografía expresa una paradoja. Literalmente significa texto de luz; es decir, fotografiar es escribir con luz. La paradoja, según Roland Barthes, es que en la imagen fotográfica coexisten dos mensajes: el analagon perfecto de la realidad (el efecto de la luz sobre la placa fotográfica) y la retórica del lenguaje fotográfico (producto de la historia y la cultura). El primer mensaje denota, es realista; el segundo mensaje connota, es simbólico. Dicho de otra manera, la fotografía es, en las palabras de James Agee, el "lenguaje de la realidad".$\underline{5}$ El realismo paradójico barthesiano combina precisamente el realismo mimético y el estudio de la vida de los signos en la sociedad, es decir, la semiología. -

En cambio, el siglo XIX estaba dominado por un realismo que, sin paradoja, fijaba su vista sobre la imagen como si fuera un reflejo del espejo, la pura mimesis. En este esquema decimonónico, la fotografía objetiva se oponía al arte subjetivo.₹- Durante el siglo XIX, varios estilos realistas aparecieron. El primer estilo de gran difusión fue la fotografía de estudio la cual rápidamente desplazó a los artistas retratistas. Luego, el desarrollo tecnológico gradualmente aumentó la movilidad de la cámara y los fotógrafos inventaron nuevas convenciones, muchas veces con pretensiones científicas, para los propósitos de la antropología, del periodismo, de la geografía (especialmente para el viajero de butaca) y de la documentación de condiciones sociales y urbanas. $\underline{8}$ A pesar de estos diferentes estilos y usos, la legitimidad y autoridad de estas fotografías se basó en el realismo mimético.?2Durante el siglo XIX, el reto principal al realismo vino de aquellos fotógrafos que intentaron introducir la creatividad e inculcar los valores estéticos al "arte fotográfico" más allá de los estilos realistas. $\underline{10}$

No es hasta la mitad del siglo XX que varios autores comienzan a cuestionar seriamente el realismo mimético, ya no desde un punto de vista artístico, sino desde el punto de vista de las normas sociales que "producen", "transforman" o dirigen la "lectura" de la imagen. Philippe Dubois agrupa las diversas persepectivas críticas del realismo decimonónico en cuatro tendencias interpretativas: la semiología, las teorías de la percepción visual, la crítica ideológica y el estudio de las convenciones sociales $\stackrel{11}{ }$ Con la posible excepción de la semiología, estas tendencias se concentran en los varios procesos antes (la tecnología, la elección del tema, los estilos convencionales, las prácticas sociales) y después (la recepción, la interpretación, la difusión, la legitimación y los usos sociales) de la imagen como tal. Pierre Bourdieu, en su estudio de la práctica de la fotografía en Francia en los años sesenta resalta la noción de que solamente ciertas escenas son "fotografiables", especialmente en los contextos familiares y de los clubes de fotografía. Basándose en entrevistas 